\title{
DETECTION OF ENTEROTOXINS GENES IN COAGULASE-NEGATIVE STAPHYLOCOCCI ISOLATED FROM FOODS
}

\author{
Maria de Lourdes Ribeiro de Souza da Cunha*; Eliana Peresi; Regina Adriana Oliveira Calsolari; \\ João Pessoa Araújo Júnior
}

Departamento de Microbiologia e Imunologia, Instituto de Biociências, Universidade Estadual Paulista, Botucatu, SP, Brasil

Submitted: August 30, 2004; Returned to authors for corrections: May 27, 2005; Approved: January 18, 2006

\begin{abstract}
Staphylococcal food poisoning is caused by ingestion of enterotoxins preformed in the food contaminated essentially through human manipulation or raw material obtained from animals. Although coagulase-positive Staphylococcus aureus is the main agent responsible for food intoxication, some researches emphasise that coagulase-negative staphylococci (CNS) are able to produce staphylococcal enterotoxins and may be a potential cause of food poisoning. In the present study CNS were isolated from foods and the toxigenic capacity of the strains determined. A total of 88 food samples were analysed and $22.7 \%$ were positive for CNS strains. Staphylococcal counts ranged from $3.0 \times 10^{2}$ to $1.4 \times 10^{6} \mathrm{CFU} / \mathrm{g}$ or $\mathrm{mL}$ of food examined. S. epidermidis predominated among the isolates (40\%). Further isolates included S. xylosus (20\%), S. warneri (20\%), S. saccharolyticus (15\%), and S. hominis (5\%). Four isolates were positive for enterotoxin genes, as detected by polymerase chain reaction, with sea being the predominant gene. Although no enterotoxin production was detected by the reverse passive latex agglutination method, the data showed that the toxigenic capacity of CNS should not be ignored, requiring investigation of this group of microorganisms in food.
\end{abstract}

Key words: coagulase-negative staphylococci, PCR, enterotoxins

\section{INTRODUCTION}

Staphylococcus aureus enterotoxins are the most frequent causes of food poisoning, with outbreaks caused by mishandling of foods after heat treatment $(21,23)$. The heat destroys the vegetative bacterial microbiota in food, and the non competitive staphylococci, introduced by inadequate handling process, may grow.

Although enterotoxins are produced mainly by coagulasepositive staphylococci, some coagulase-negative staphylococci (CNS), involved in a variety of human and animal infections (11), have also raised interest. Very little is known about the growth of CNS in foods. These strains have rarely been implicated in food poisoning because they do not grow rapidly in foods. Nevertheless CNS can contaminate foods because humans are common carriers of these microorganisms and some may be related to specific human infections (4).
Since immunoassays require a detectable amount of toxin, molecular techniques can complement the assay through detection of staphylococcal enterotoxin genes as important tool in the microbiology laboratory. Taking into account that the toxigenic potential of CNS is often neglected, in the present study enterotoxin genes in CNS strains isolated from foods were analysed by PCR and the results correlated with latex agglutination assay data.

\section{MATERIALS AND METHODS}

\section{Food samples}

A total of 88 food samples were analysed, including bakery goods $(n=38)$, milk $(n=18)$, snacks $(n=11)$, white cheese $(n=10)$, sandwich $(n=8$,$) and pork meat (n=3)$, purchased from local markets or delicatessens in Botucatu, SP (Brazil) for a period of twelve months (2003). The interval between the sampling and the analysis was less than one hour.

*Corresponding Author. Mailing address: Departamento de Microbiologia e Imunologia, Instituto de Biociências, UNESP, Caixa Postal 510. 18618-000, Botucatu, SP, Brasil. Tel.: (+5514) 3811-6058. Fax: (+5514) 3815-3744. E-mail: cunhamlr@ibb.unesp.br 


\section{Isolation of staphylococci}

Twenty-five grams of each sample was suspended in 225 $\mathrm{mL}$ peptone water, and $0.1 \mathrm{~mL}$ of $10^{-1}$ to $10^{-6}$ dilutions was spread on the surface of Baird-Parker agar. The plates were incubated for $48 \mathrm{~h}$ at $37^{\circ} \mathrm{C}$ and typical colonies (black to dark grey, smooth, convex, well-defined contours, surrounded or no by a dull halo) were counted and the number expressed in CFU/g or $\mathrm{mL}$.

\section{Identification of coagulase-negative staphylococci}

Representatives of each colony type were checked by Gram method for purity and morphology, and submitted to catalase and coagulase tests. The genus Staphylococcus was differentiated from Micrococcus by glucose oxidation and fermentation tests, resistance to bacitracin ( $0.04 \mathrm{U}$, absence of an inhibition halo or formation of a halo of up to $9 \mathrm{~mm}$ ), and sensitivity to furazolidone (100 mg, inhibition halo of 15 to $35 \mathrm{~mm})(2)$.

CNS were identified by simplified biochemical test scheme proposed by Kloos and Schleifer (10) and Kloos and Bannerman (11), which is based on the utilization of xylose, arabinose, sucrose, trehalose, mannitol, maltose, lactose, xylitol, ribose, and fructose, characterization of hemolysis, reduction of nitrate, presence of urease and ornithine decarboxylase, and resistance to novobiocin.

\section{Toxin production}

Staphylococcal enterotoxin was produced using the dialysis bag method described by Donnelly et al. (8). A 30 to $40 \mathrm{~cm}$ dialysis bag (Cut-Off 12,000-16,000 MW, Inlab) was previously washed with distilled water, closed at one end, filled with $50 \mathrm{~mL}$ of double-concentrated brain heart infusion broth (BHI), and the other end closed. The bag, bended to a "U" shape, was placed in a $250 \mathrm{~mL}$ Erlenmeyer flask and autoclaved for $15 \mathrm{~min}$ at $121^{\circ} \mathrm{C}$. The flask was added of $18 \mathrm{~mL}$ of $0.02 \mathrm{M}$ phosphate buffer $\mathrm{pH} 7.4$ in $0.9 \% \mathrm{NaCl}$, inoculated with staphylococci previously cultured in $5 \mathrm{~mL} \mathrm{BHI}$ at $37^{\circ} \mathrm{C} / 18 \mathrm{~h}$. After incubation at $37^{\circ} \mathrm{C}, 200 \mathrm{rpm}$ for $24 \mathrm{~h}$, the culture was centrifuged at $8000 \mathrm{~g} /$ $10 \mathrm{~min}$ at $4^{\circ} \mathrm{C}$ and the supernatants stored at $-20^{\circ} \mathrm{C}$ and in liquid nitrogen until use.

\section{Detection of enterotoxins}

For the detection of toxins by reverse passive latex agglutination (RPLA) method, the supernatants concentrated in dialysis bags (8) were filtered through an $8 \mu \mathrm{m}$ Millipore membrane to avoid nonspecific reactions. Extracellular enterotoxins were detected by RPLA method as described by Shingaki et al. (20) using the SET-RPLA-T900 kit for the detection of SEA, SEB, SEC and SED (Oxoid Diagnostic Reagents). Briefly, microplate wells with a V-shaped bottom were inoculated with $25 \mu \mathrm{L}$ of the supernatant and $25 \mu \mathrm{L}$ latex sensitised with anti-enterotoxins. Standard toxins (provided by manufacturer, Oxoid Diagnostic Reagents) were used as positive controls and the occurrence of nonspecific reactions was tested by addition of $25 \mu \mathrm{L}$ of the supernatant to $25 \mu \mathrm{L}$ of control latex. The plates were covered with cellophane and homogenised in a micromixer for $3 \mathrm{~min}$. After incubation for 20 to $24 \mathrm{~h}$ at environmental temperature, the results were recorded according to the agglutination pattern described by the manufacturer. Positive reactions were classified as $(+),(++)$, and (+++), while formation of a pink bud was interpreted as a negative result.

\section{Detection of enterotoxin genes DNA extraction}

Total DNA was extracted from CNS strains cultured on blood agar, inoculated individually into BHI broth and incubated at $37^{\circ} \mathrm{C} / 24 \mathrm{~h}$. The GFX kit (Amersham Biosciences) was used for DNA extraction by manufacturer's protocol, which consists of initial digestion of the staphylococcal cells with lysozyme $(10 \mathrm{mg} / \mathrm{mL})$ and proteinase $\mathrm{K}(20 \mathrm{mg} / \mathrm{mL})$. Then $500 \mu \mathrm{L}$ of the extraction solution was added, and the mixture was centrifuged (5000 $\mathrm{g} / 1 \mathrm{~min})$. The supernatant was then transferred to a GFX column and centrifuged $(5000 \mathrm{~g} / 1 \mathrm{~min})$. The eluent was discarded, and $500 \mu \mathrm{L}$ of extraction solution was again added to the column. After centrifugation and disposal of the collected eluent, $500 \mu \mathrm{L}$ of the wash solution was added to the column and the column was centrifuged at $20800 \mathrm{~g} / 3 \mathrm{~min}$. The column was then transferred to a $1.5-\mathrm{mL}$ tube and $200 \mu \mathrm{L}$ Milli-Q water heated at $70^{\circ} \mathrm{C}$ was used for elution under centrifugation (5000 g/ $1 \mathrm{~min})$.

\section{PCR}

PCR was carried out in 0.5 -mL microcentrifuge tubes added of 20 pmol of each primer (Table 1), 2.5 U Taq DNA polymerase, $200 \mu \mathrm{M}$ dNTPs, $20 \mathrm{mM}$ Tris- $\mathrm{HCl}$, pH 8.4, $0.75 \mathrm{mM} \mathrm{MgCl}_{2}$, and $5 \mu \mathrm{LDNA}$ (total volume of $50 \mu \mathrm{L}$ ). A negative control in which DNA was replaced with water was run in parallel in all reactions. Amplification was performed with an MJ Research PTC-100 thermocycler as described by Johnson et al. (9) with some modification, which consisted of a first cycle at $94^{\circ} \mathrm{C}$ for $4 \mathrm{~min}$, denaturation at $94^{\circ} \mathrm{C}$ for $2 \mathrm{~min}$, annealing at $55^{\circ} \mathrm{C}$ for $1 \mathrm{~min}$ and $30 \mathrm{sec}$, and extension at $72^{\circ} \mathrm{C}$ for $1 \mathrm{~min}$ and $30 \mathrm{sec}$, followed by a second cycle of denaturation at $94^{\circ} \mathrm{C}$ for $2 \mathrm{~min}$, annealing at $53^{\circ} \mathrm{C}$ for $1 \mathrm{~min}$ and $30 \mathrm{sec}$, and extension at $72^{\circ} \mathrm{C}$ for $1 \mathrm{~min}$ and 30 sec. In the third cycle, the annealing temperature was reduced to $51^{\circ} \mathrm{C}$, followed by additional 37 cycles at $94^{\circ} \mathrm{C}$ for $2 \mathrm{~min}, 51^{\circ} \mathrm{C}$ for $1 \mathrm{~min}$ and $30 \mathrm{sec}$ and $72^{\circ} \mathrm{C}$ for $1 \mathrm{~min}$ and $30 \mathrm{sec}$. At the end of the 40 cycles, the tubes were incubated at $72^{\circ} \mathrm{C}$ for $7 \mathrm{~min}$ and stored at $4^{\circ} \mathrm{C}$.

\section{Analysis of the amplified products \\ Amplification efficiency was determined on 2\% agarose gels in $1 \mathrm{X}$ TBE buffer stained with ethidium bromide. The size of the amplified products was compared with 50- and 100-kb standards and the gels were photographed under UV transillumination.}




\section{RESULTS}

Table 2 shows the distribution of CNS according to species and food analysed, slowing that twenty food samples were positive for CNS species. Of the $20 \mathrm{CNS}$ isolates, 12 were isolated from bakery goods, 2 from milk, 1 from cheese, 2 from sandwiches, and 3 from pork meat.

CNS counts in the foods ranged from $3.0 \times 10^{2}$ to $1.4 \times 10^{6}$ $\mathrm{CFU} / \mathrm{g}$ or $\mathrm{mL}$, except for snacks, where no staphylococci were isolated (Table 3).

S. epidermidis was the most predominant specie, accounting for $40 \%$ of all CNS, followed by S. xylosus (20\%), S. warneri (20\%), S. saccharolyticus (15\%), and S. hominis (5\%).

The gene specific analysis by PCR for enterotoxin production revealed sea gene in three CNS isolates, while sec-1 gene was detected in only one isolate (Table 4). Despite potentially toxigenic strains of CNS were detected by molecular tool, the analysis of enterotoxin by RPLA method showed negative results.

The sea gene was detected in one S. epidermidis isolated from chocolate cream-filled puffs, in one $S$. xylosus isolate from cream-filled puffs and in one S. hominis from apple pie. The sec1 gene was detected in only one $S$. xylosus isolated from fruit pie.

\section{DISCUSSION}

As shown in Table 2, S. epidermidis was the most frequently isolated species (40\%). This species is a common inhabitant of human skin and mucous membranes of individuals manipulating food and animals, and is able to contaminate raw products and processed foods (4).

Both $S$. warneri and $S$. xylosus were the second most frequent species in our study (20\%). In a study carried out by Udo et al. (24) with restaurant workers, the prevalent CNS species on the hands of food handlers were S. hominis (23.6\%), S. warneri (20.6\%) and S. epidermidis (3.4\%). Since human nares and fingers are the main sources of $S$. aureus $(16,22)$, and because CNS inhabit the human skin and mucous membranes, these microorganisms can contaminate food if these are not handled properly. Therefore, enterotoxigenic CNS strains may contribute to staphylococcal food poisoning (4).

In the present study, staphylococcal enterotoxin genes were detected in one S. epidermidis isolate, two $S$. xylosus isolates and one S. hominis isolate (Table 4).

Valle et al. (25) determined the enterotoxigenic character of staphylococci isolated from the skin, nasal mucosa and milk of

Table 1. Primers used for the detection of staphylococcal enterotoxin genes.

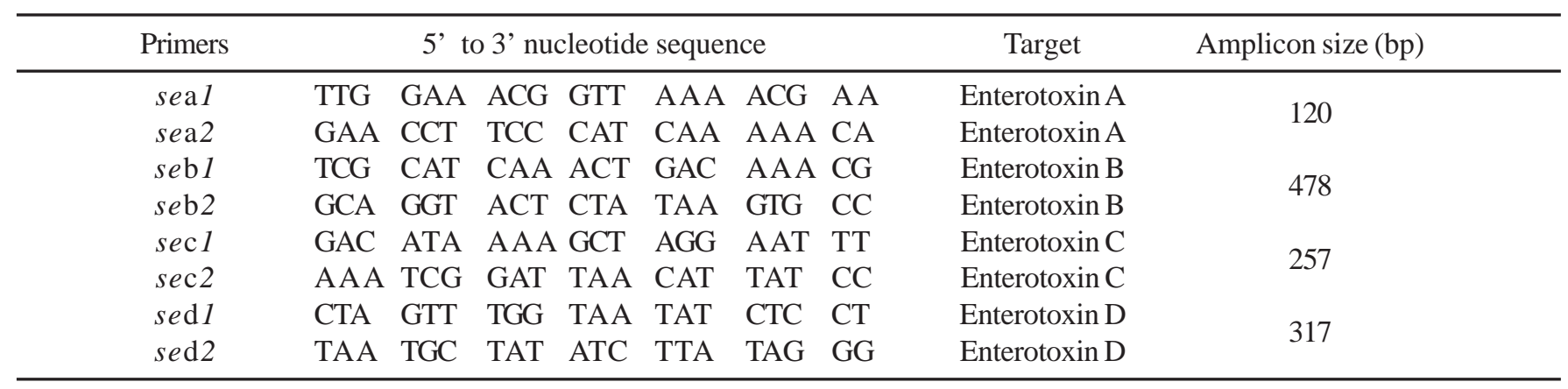

Source: Johnson et al., 1991 (9).

Table 2. Frequency of coagulase-negative staphylococci (CNS) isolated from foods.

\begin{tabular}{|c|c|c|c|c|c|c|c|}
\hline Species & $\begin{array}{c}\text { Isolates } \\
n=20\end{array}$ & $\begin{array}{c}\text { Bakery goods } \\
n=38\end{array}$ & $\begin{array}{c}\text { Snack } \\
\mathrm{n}=11\end{array}$ & $\begin{array}{l}\text { Milk } \\
\mathrm{n}=18\end{array}$ & $\begin{array}{c}\text { White cheese } \\
n=10\end{array}$ & $\begin{array}{c}\text { Sandwich } \\
n=8\end{array}$ & $\begin{array}{c}\text { Pork meat } \\
n=3\end{array}$ \\
\hline S. epidermidis & $8(40.0)$ & $4(20.0)$ & - & $2(10.0)$ & - & $2(10.0)$ & - \\
\hline S. hominis & $1(5.0)$ & $1(5.0)$ & - & - & - & - & - \\
\hline S. warneri & $4(20.0)$ & $3(15.0)$ & - & - & $1(5.0)$ & - & - \\
\hline S. saccharolyticus & $3(15.0)$ & - & - & - & - & - & $3(15.0)$ \\
\hline
\end{tabular}

$\mathrm{N}=$ Number of isolates CNS of the 88 samples analysed; $\mathrm{n}=$ Total number of samples analysed. 
Table 3. Number of coagulase-negative staphylococci (CNS) in foods.

\begin{tabular}{lllc}
\hline \multicolumn{1}{c}{ Food } & $\begin{array}{c}\text { Isolates } \\
\mathrm{N}(\%)\end{array}$ & \multicolumn{1}{c}{ Species } & $\begin{array}{c}\text { Average Count } \\
\text { CFU/g or mL }\end{array}$ \\
\hline Bakery goods $(\mathrm{n}=38)$ & $4(20.0)$ & S. epidermidis & $1.3 \times 10^{3}$ \\
& $4(20.0)$ & S. xylosus & $6.0 \times 10^{4}$ \\
& $1(5.0)$ & S. hominis & $5.5 \times 10^{4}$ \\
& $3(15.0)$ & S. warneri & $3.2 \times 10^{4}$ \\
Milk $(\mathrm{n}=18)$ & $2(10.0)$ & S. epidermidis & $3.2 \times 10^{4}$ \\
White cheese $(\mathrm{n}=10)$ & $1(5.0)$ & S. warneri & $1.4 \times 10^{6}$ \\
Sandwich $(\mathrm{n}=8)$ & $2(10.0)$ & S. epidermidis & $7.2 \times 10^{4}$ \\
Pork meat $(\mathrm{n}=3)$ & $3(15.0)$ & S. saccharolyticus & $3.0 \times 10^{2}$ \\
\hline
\end{tabular}

$\mathrm{n}=$ Total number of samples analysed.

Table 4. Detection of toxin genes by PCR in CNS species isolated from foods.

\begin{tabular}{lcccc}
\hline Species & sea & seb & sec-1 & sed \\
\hline S. epidermidis & 1 & - & - & - \\
S. xylosus & 1 & - & - & - \\
S. xylosus & - & - & 1 & - \\
S. hominis & 1 & - & - & - \\
S. warneri & - & - & - & - \\
S. saccharolyticus & - & - & - & - \\
\hline Total & 3 & - & 1 & - \\
\hline
\end{tabular}

sea, seb, sec-1, and sed: enterotoxins genes A, B, C and D, respectively.

133 healthy goats. Twenty-two percent of CNS strains produced enterotoxins, including $S$. caprae, S. xylosus, S. warneri and $S$. epidermidis.

Analysis of the toxigenic profile of CNS isolated in our study by PCR revealed the presence of the sea gene in one S. xylosus isolate, one $S$. hominis isolate and one $S$. epidermidis isolate (Table 4). It has been widely accepted that most staphylococcal food intoxications are caused by the ingestion of enterotoxin $\mathrm{A}$ $(17,18,26)$. The presence of the sec-1 gene was observed in one S. xylosus isolate. All theses toxigenic CNS were isolated from bakery goods. Bakery goods covered and filled with cream are leading causes of food poisoning worldwide $(1,5,7)$.

The enterotoxigenicity of CNS has been described by several investigators $(6,14,25)$, and questioned by others (3), but few studies have been conducted to determine the enterotoxigenic capacity of CNS in foods. In this study, a small number of CNS harboured enterotoxin genes but, their detection was important because confirms that CNS isolated from foods can produce enterotoxins. These results confirm the findings reported by Crass and Bergdoll (6) who isolated enterotoxin- producing CNS from food implicated in a food poisoning outbreak.

Comparing the PCR and RPLA data, the isolates were shown to be PCR-positive for enterotoxin gene did not evidence detectable production of enterotoxin by RPLA method. Similar findings have been reported by others $(9,19)$ and might be due to toxin production below the detection limit of the RPLA method or to the non-expression of genes. According to Schmitz et al. (19), in clinical practice, staphylococcal strains carrying a toxin gene should be considered potential producers of this toxin since toxin production in vivo cannot be excluded. Many factors affect $S$. aureus growth and enterotoxin production in foodstuffs, such as the presence of specific amino acids that vary with the strains (15), glucose, $\mathrm{pH}$, acetic acid, lactic acid, sodium chloride and competing microorganisms (12). Thus considerable research effort is still required for better understanding of the interactions between CNS and the food matrix, and the mechanisms of enterotoxin production in foodstuffs.

PCR was found to be a rapid and reliable method for the identification of genes responsible for the production of staphylococcal toxins. The determination of the enterotoxigenicity of strains is mainly based on immunological methods, which depend on the concentration of the toxin produced and, therefore, might not detect low-producing strains.

The importance of our results lies not only in scientific aspects considering the scarcity of available data in this respect, but in providing practical information about food safety, which is of great importance since some CNS species, such as $S$. xylosus, are used as a starter culture in fermented meat products (13). In addition, the present results confirm the need for further studies in order to better characterize the enterotoxigenic potential of CNS in foods.

\section{ACKNOWLEDGEMENTS}

We thank Fundação de Amparo à Pesquisa do Estado de São Paulo (FAPESP) for financial support.

\section{RESUMO}

\section{Detecção de genes de enterotoxinas em estafilococos coagulase-negativa isolados de alimentos}

A intoxicação alimentar estafilocócica ocorre devido à ingestão de alimentos contaminados com enterotoxinas. Essa contaminação tem sido oriunda, principalmente, da manipulação humana, ou de matérias-primas procedentes de animais portadores. Embora Staphylococcus aureus coagulase positiva, seja o principal agente de intoxicação alimentar, alguns 
pesquisadores enfatizam que os estafilococos coagulasenegativa $(\mathrm{ECN})$ podem produzir as enterotoxinas estafilocócicas, podendo contribuir para a intoxicação alimentar. Este estudo teve como objetivos isolar os ECN de alimentos e verificar a capacidade enterotoxigênica dessas linhagens. Foram estudadas 88 amostras de alimentos, sendo que $22,7 \%$ foram positivas para ECN com crescimento entre $10^{2}$ e $10^{6} \mathrm{UFC} / \mathrm{g}$ or mL. A espécie predominante dentre as linhagens isoladas foi $S$. epidermidis (40\%), seguido por S. warneri (20\%), S. xylosus (20\%), S. saccharolyticus (15\%) e S. hominis (5\%). Entre as linhagens isoladas, quatro apresentaram genes para produção de enterotoxinas pelo método de Reação da Polimerase em Cadeia (PCR), com predominância do gene sea. Não se detectou a produção de enterotoxina pelo método de aglutinação em látex (RPLA). Através dos resultados obtidos, observou-se que os ECN isolados de alimentos não devem ser ignorados quanto à sua capacidade toxigênica, necessitando de maior estudo e atenção para melhor caracterização desse grupo de microrganismos em alimentos.

Palavras-chave: estafilococos coagulase-negativa, PCR, enterotoxinas

\section{REFERENCES}

1. Anunciação, L.L.C.; Linardi, V.R.; Carmo, L.S.; Bergdoll, M.S. Production of staphylococcal enterotoxin A in cream-filled cake. Rev. Microbiol., 26, 259-263, 1995.

2. Baker, J.S. Comparison of various methods for differentiation of staphylococci and micrococci. J. Clin. Microbiol., 19, 875-879, 1984.

3. Becker, K.; Haverkamper, G.; von Eiff, C.; Roth, R.; Peters, G. Survey of staphylococcal enterotoxin genes, exfoliative toxin genes, and toxic shock syndrome toxin 1 gene in non-Staphylococcus aureus species. Eur. J. Clin. Microbiol. Infect. Dis., 20, 407-409, 2001.

4. Bergdoll, M.S. Importance of staphylococci that produce nanogram quantities of enterotoxin. Zbl Bakt., 282: 1-6, 1995.

5. Cerqueira-Campos, M.L.; Furlanetto, S.M.P.; Iaria, S.T.; Bergdoll, M.S. Staphylococcal food poisoning outbreaks in São Paulo (Brazil). Rev. Microbiol., 24, 261-264, 1993.

6. Crass, B.A.; Bergdoll, M.S. Involvement of coagulase-negative staphylococci in toxic shock syndrome. J. Clin. Microbiol., 23, 4345, 1986.

7. Dias, R.S.; Carmo, L.S.; Silva, M.C.C. Surto de toxinfecção alimentar causado pela ação simultânea de enterotoxina estafilocócica e Salmonella enteritidis - Estudo de caso. Rev. Inst. Adolfo Lutz, 58, 7-11, 1999.

8. Donnelly, C.B.; Leslie, J.E.; Black, I.A.; Lewis, K.H. Serological identification of enterotoxigenic staphylococci from cheese. Appl. Microbiol., 15, 1382-1387, 1967.

9. Johnson, W.M.; Tyler, S.D.; Ewan, E.P.; Ashton, F.E.; Pollard, D.R.; Rozee, K.R. Detection of genes for enterotoxins, exfoliative toxins, and toxic shock syndrome toxin 1 in Staphylococcus aureus by the polymerase chain reaction. J. Clin. Microbiol., 29, 426-430, 1991.

10. Kloos, W.E.; Schleifer, K.H. Simplified scheme for routine identification of human Staphylococcus species. J. Microbiol., 1, 82-88, 1975.

11. Kloos, W.E.; Bannerman, T.L. Staphylococcus and Micrococcus. In: Murray, P.R.; Baron, E.J.; Pfaller, M.A.; Tenover, F.C.; Yolken, R.H. (eds.). Manual of Clinical Microbiology. American Society Microbiology, Washington, 1995, p.282-298.

12. Loir, Y.L.; Baron, F.; Gautier, M. Staphylococcus aureus and food poisoning. Genet. Mol. Res., 2, 63-76, 2003.

13. Montel, M.C. Fermented meat products. In: R.K. Robinson, C.A. Batt, P.D. Patel. Encyclopedia of Food Microbiology, Academic Press, London, 2000, p.744-753.

14. Olsvik, O.; Fossum, K.; Berdal, B.P. Staphylococcal enterotoxin A, $\mathrm{B}$, and $\mathrm{C}$ produced by coagulase-negative strains within the family Micrococcaceae. Acta. Pathol. Microbiol. Immunol., 2, 92-96, 1982.

15. Onoue, Y.; Mori, M. Amino acid requirement for growth and enterotoxin production by Staphylococcus aureus in chemically defined media. Int. J. Food Microbiol., 36, 77-82, 1997.

16. Polledo, J.J.F.; Garcia, M.L.; Moreno, B.; Menes, I. Importance of food handlers as a source of enterotoxigenic staphylococci. Zentrabl. Bacteriol. Mikrobiol. Hyg., 181, 364-367, 1985.

17. Rasooly, A.; Rasooly, R.S. Detection and analysis of staphylococcal enterotoxin $\mathrm{A}$ in food by Western immunoblotting. Int. J. Food Microbiol., 41, 205-212, 1998.

18. Rasooly, A.; Ito, Y. Toroidal coil countercurrent chromatography separation and analysis of staphylococcal enterotoxin A (SEA) in milk. J. Liq. Chrom. Rel. Technol., 22, 1285-1293, 1999.

19. Schmitz, F.J.; Steiert, M.; Hofmann, B.; Verhoef, J.; Hadding, U.; Heinz, H.P.; Kohrer, K. Development of a multiplex-PCR for direct detection of the genes for enterotoxin $\mathrm{B}$ and $\mathrm{C}$, and toxic shock syndrome toxin-1 in Staphylococus aureus isolates. J. Med. Microbiol., 47, 335-340, 1998.

20. Shingaki, M.H.; Igarashi, H.; Fujikawa, H.; Ushioda, H.; Terayama, T.; Sakai, S. Study on reverved passive latex agglutination for the detection of staphylococcal enterotoxins A-C. Annu. Rep. Tokyo Metr. Res. Lab. Plubl. Heth., 32, 128-31, 1981.

21. Smith, J.L.; Buchanan, R.L.; Palumbo, S.A. Effect of food environment of staphylococcal enterotoxin synthesis: A review. $J$. Food Protect., 46, 545-555, 1983.

22. Soares, M.J.S.; Miyazaki, N.H.T.; Noleto, A.L.S.; Figueiredo, A.M.S. Enterotoxin production of Staphylococcus aureus and detection of Brazilian epidemic MRSA clone (III:B:A) among isolates from food handlers. J. Med. Microbiol., 46, 214-221, 1997.

23. Soriano, J.M.; Font, G.; Moltó, J.C.; Mañes, J. Enterotoxigenic staphylococci and their toxins in restaurant foods. Trends Food Sci. Tech., 13, 60-67, 2002.

24. Udo, E.E.; Al-Bustan M.A.; Jacob, L.E.; Chugh, T.D. Enterotoxin production by coagulase-negative staphylococci in restaurant workes from Kuwait City may be a potential cause of food poisoning. $J$. Med. Microbiol., 48, 819-823, 1999.

25. Valle, J.; Gomez-Lucia, E.; Piriz, S.; Goyache, J.; Orden, J.A.; Vadillo, S. Enterotoxin production by staphylococci isolated from goats. Appl. Environ. Mirobiol., 56, 1323-1326, 1990.

26. Zschöck, M.; Botzler, D.; Blöcher, S.; Sommerhäuser, J.; Hamann, H.P. Detection of genes for enterotoxins (ent) and toxic shock syndrome toxin-1 (tst) in mammary isolates of Staphylococcus aureus by polymerase chain reaction. Int. Dairy J., 10, 569-574, 2000. 